\title{
The Milieu of Accountability of Early \\ Companies in the Qīng Dynasty: Evidence from the Shànghăi-based Print Media
}


The Milieu of Accountability of Early Companies in the Qīng Dynasty: Evidence from the Shànghăi-based Print Media

Manuscript by:

Lan Peng* (Zhongnan University of Economics and Law) and Alistair Brown (Curtin University)

* Contact Author

Lan Peng

Associate Professor

School of Accounting and Finance

Zhongnan University of Economics and Law (ZUEL)

182\# Nanhu Road, Donghu Gaoxin District

Wuhan,Hubei,P.R.of China, 430073

E-mail address: peng8881an@qq.com

peng8881an@aliyun.com

Phone: 008618995610963

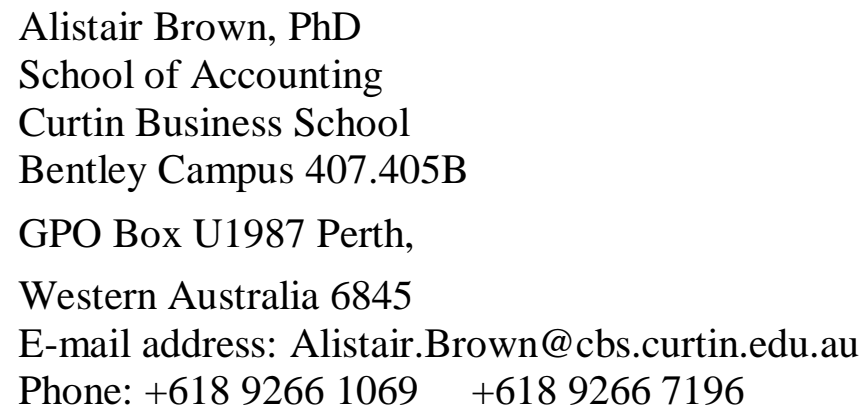




\begin{abstract}
This study looks at evidence from the Shànghăi (Shanghai)-based print media of the accountability of early Chinese companies from the middle period of the Qing (Qing) Dynasty when the Opium War broke out in 1840 until the imperial monarchy's overthrow in the revolution of 1911. The Qing Dynasty is known for its technical accounting stagnation. Yet, an examination of the Shànghăi-based print media shows the existence of a strong sense of public reporting by early companies of the Qing Dynasty. The findings of this study indicate that the print media displayed a rich milieu of accountability of these early companies by incorporating components of Western and Chinese benchmarks of accountability expressed in commercial metrics and key financial ratios.
\end{abstract}

Key words: accountability; Guānlì (Guanli) dividends; early Chinese companies; Qīng Dynasty; print media.

\title{
Introduction
}

The role in which accounting and accountability plays in power and governance has considerable interest in Chinese accounting history (Guō 1988a; 1988b; Aiken and Lu 1998; 1993a; 1993b; 1993c; Lin 1992; Fu 1971) but very little has been written about the development of written financial reporting that informed this accountability in the print media during the middle period of 1840 to 1911 . This point is an important one because while Auyeung and Ivory (2003) suggest that China underwent a period of accounting stagnation during the Qing (Qing) Dynasty, there appears to be evidence that the Chinese print media were eager to showcase Western and early Chinese company accountabilities.

These early companies in the Qing Dynasty operated in uncertain circumstances. A massive upheaval of the Chinese social environment arose not only due to the events of the First and Second Opium War, Sino-France War, Sino-Japanese War and during the offence of the eight-power allied forces in the China War but also due to the deep financial crises of 1883 and 1910. Despite these upheavals, commercial activity increased during the Qing Dynasty with early Chinese companies growing in size and profits, resulting in expectations for an account of those profits using a Western form of reporting.

Although the late Qing Dynasty's economy was characterised by government corruption and European-imposed unequal treaties, extraterritoriality and treaty ports, many reforms were initiated to improve imperial governance. The Self-Strengthening Movement, which to modernise institutions and the military, and develop communications, industry and 
transportation, was undermined by the First Sino-Japanese war. The Qing rulers lost possession of Táiwān (Taiwan) and influence over Korea. The Hundred Days Reform of 1898 attempted to reform China's cultural, educational political institutions but was rejected by the Empress Dowager Cíxī (Cixi). Fiscal and legal reforms were also introduced, including the Commercial Code and Company Law Reform through Survey in 1909, incorporating various commercial codes and company laws around the world and taking into consideration China's commercial developments (Shuài 2001). The Commercial Code and Company Law Reform through Survey were informed by precepts from British company law and the German commercial code, as well as the Japanese commercial code. Financial institutions also proliferated, including the Shànghăi International Settlement, Shànghăi Sharebrokers Association and the Shànghăi Stock Exchange.

The great influx of fiscal and legal reforms brought with it the opportunity to take on introduced Western bookkeeping ideas, which was supposed to provide to Chinese organisations an improved means of measuring profits, improving accuracy and checking errors, thus making accounting records more reliable (Auyeung and Ivory 2003). Nevertheless, for a number of social and ideological reasons, the indigenous Chinese system of reporting persisted in the Qing Dynasty, with substantial resistance to the wholesale transfer of Western forms of reporting.

One Chinese industry that appeared to welcome the trappings of Western bookkeeping, yet still retain its allegiance to the Chinese sense of accountability, was the Shànghăi-based print media industry. During the late period of the Qinng Dynasty, the Shànghăi-based print media reported information about early Chinese companies reporting that appears to have given readers a sense of accountability of those early companies. In this context, this study poses the following research question: During the late Qing Dynasty, what evidence of accountability existed in the reports by the Shànghăi-based print media reports of early Chinese companies reporting?

The paper is structured as follows. The following section considers the theory of alternative reporting models in the context of the Qing Dynasty. A discussion is then presented on the Shànghăi print media, in particular its development in the Qīng Dynasty and its reporting of early Chinese companies reporting. This is followed by the analysis of the results of the print media's disclosure of the early Chinese companies reporting. A reflection on early Chinese companies' accountability is then explored. Finally, conclusions of the study's findings are offered. 


\section{Alternative reporting models and accountability}

The theory of alternative reporting models (Traditional, Western-narrow and Western-broad) recognises that different forms of accountability may exist across a broad spectrum of reporting models ranging from a Traditional reporting model based on an indigenous accounting system to Western-broad comprehensive reporting model based on civic-based practices of Western democratic countries (Brown 2011). If the indigenous Chinese system of reporting that persisted in the Qing Dynasty is seen as closely aligned to the Traditional reporting model and the introduction of technical forms of Western bookkeeping to the Qing Dynasty is taken as an example of the Western-narrow reporting model, then there is room to acknowledge the different forms of accountabilities that arose from each reporting model.

The Traditional reporting model focuses on deference to communal customs and conditions in contrast to the financial focus of the Western-narrow reporting model and the societal focus of the Western-broad model (Brown and Tower 2002). The traditional reporting model is characterised by an incentive to generate written reports for stewardship but there rests an 'accountability of undecided space' (Brown 2011, 172). This model contrasts with Western-narrow reporting with its focus on generating narrow, financially-based, written reports providing an accountability of agency, and the Western-broad reporting with its high values given to written accounts that inform on matters of corporate governance and social responsibility, providing an accountability of civic culture. The Western-narrow model recognised the need for timely and accurate financial information with an emphasis on income statement and balance sheet figures. According to Brown (2011), the Traditional reporting model provides selective patterns of visibility and obligations.

Gardella $(1992,317)$ explains that during the Qing Dynasty, indigenous Chinese business went through 'sprouts of capitalism' and that account-keeping techniques 'were adapted to meet the basic requirements of small retail shops and the complex needs of large commercial firms and native banks' (Gardella 1992). Gardella (1982) recognised that while a sense of rational economic authority characterised Western reporting to render a distinct form of economic visibility to satisfy the needs of a modern capitalist enterprise, a pattern of traditional obligations and patriarchal authority prevailed over Chinese traditional reporting to offer 'pragmatically evolved responses to a host of highly individualised problems of managing and controlling business enterprises and households' (Gardella 1982, 61). This form of Traditional reporting was not an impediment to accountability. Rather,

...there were no inherent obstacles to rational commercial record keeping posed by Chinese mathematical techniques, and 'accountability' was necessary in the conduct 
everyday Chinese business activities regardless of the nature of a firm's ownership management. (Gardella 1982, 61)

\section{Western-narrow accountability}

At the time of the Qing Dynasty, the introduction of the Western double-entry accounting system to China was based on the Western-narrow reporting viewpoint that financial information needed to be prepared on a timely financial basis to satisfy accountabilities of agency and stewardship. It was assumed by the proponents of Western-narrow reporting with their predilection for double-entry accounting, that it was possible to lift the early Chinese companies reporting to a Western-narrow model of reporting calculations for profitable exchange.

Foreign investment raised these expectations of profitable exchange. Before the first Opium War in 1840, British commercial interests in China, already given full expression by the activities of the East India Company, were further bolstered by a British firm called Dent Beale \& Co. It set up a Chinese subsidiary called the Union Insurance Society of Canton that brought a flurry of share trading by Chinese and foreign merchants (Sūn 2008) ${ }^{1}$. This formal financial nexus between Chinese and non-Chinese investors was also given impetus by the British firm Jardine Matheson \& Co.'s reorganisation of its foreign subsidiary Canton Insurance Office as the Canton Guăngdōng (Guangdong) Insurance Company (Zhào 2003; Sūn 2008). In 1836, stocks of this insurance company were quickly snapped up by both Chinese and non-Chinese investors (Sūn 2008), raising issues on how to present financial statements to these diverse groups of investors.

In the early 1830s, a dispute over opium trade emerged between China and Britain. There was a concern that British distributors in their ever-increasing motivation to swell profits had begun to corrupt Chinese distributors of opium. As a consequence, during the Opium War, new public offerings in China halted. The absence of foreign competition allowed the Union Insurance Society of Canton and Canton Insurance Company the opportunity to issue further shares in China, enabling them to strengthen their financial hold on the war torn country (Sūn 2008).

The commercial success of these foreign-owned Chinese ventures was best exemplified in 1864, when Lee Wah Bank Ltd.'s stock price rose as high as $£ 25$ after opening at a par value $£ 10$ (Zhāng 2001). In 1869, the British-owned J. P. Bisset \& Co. set up operations at with substantial Chinese and foreign investment (Yáo 1919; Zhāng 2001). These successes increased the call for greater foreign-Chinese business ventures raising further amounts of capital for potential share offerings, all of which required some form of reporting that would satisfy Chinese and domestic investors. It appears that Chinese businessmen invested 
substantially in foreign joint-stock companies, particularly in the industries of shipping, insurance, banking, spinning and utilities. In Shànghăi, foreign banks and companies, such as the Shànghăi Steam Navigation Company (established in 1862) and the Hongkong and Shanghai Bank Corporation (HSBC) (established in 1865), offered shares to local residents foreign merchants (Chén 2010).

The rise of the listed company in China brought with it expectations of a Western-narrow form of written accountability, which rendered both a stewardship and signaling function. The antecedents of these colonial accounting systems had their origins in the European medieval era through communal stewardship and Christianity, which assumed that resources were available for use by the people and that property owners had a social responsibility to look after resources for the community and God (Chen 1975). These Western standards of accountability were heightened with the advent of the Western industrial revolution, particularly with the emergence of the stock company where management owed a duty of care to look after the resources of the shareholders.

\section{Chinese accountability}

China's Traditional accountability in the late Qing Dynasty was informed by a Confucian heritage and imperial governance, which was gradually being questioned by an urban elite fascinated by Western lifestyles, material goods and social practices (Rankin 2008). This imperial governance was characterised by complex bureaucratic structures, "a state that relied on a combination of extra-bureaucratic groups and formal bureaucracy" (Lufrano 2013, 98).

Past studies reveal how Traditional reporting of Chinese benchmarks of accountability were also raised at a number of levels (Gardella 1982; Guō 1988a; Fu 1989; Zhào 1992; Zhao 1987; Hsu 1991) during the Qīng Dynasty. The sìzhùfă (sizhu fa) 'four-pillar balancing method' a single-entry system to account for asset protection, while the sānjiăo zhàng (sanjiao zhang) 'three-leg bookkeeping' used three journals - the huòqīng bù (huoqing bu, cash sales and purchases journal), the yínqīng bù (yinqing bu, cash journal) and the wănglái bù (wanglai bu, personal account and transfer journal) - to account for claims and transfers. The lóngmén (longmen zhang, 'dragon-gate bookkeeping'), employed by many important wide-ranging small and medium-sized entities, used a balance equation and hé lóngmén (he longmen, matching process) to sum up calculations of jìn (jin, revenues), jiăo (jiao, expenditure), cún (cun, assets) and gāi (gai, owners' equity and liabilities) for the Jìn-Jiăo (Jin-Jiao, RevenueExpenditure) report and the Cún-Gāi (Cun-Gai, Asset-Equity-Liability) report. The sìjiăo zhàng favoured by commercial entities prepared a căixiàng report (caixiang report, profit and loss statement) and cúngāi report (cungai report, balance sheet). Although these reports were 
technically different from Western narrow reports, they offered Chinese indigenous forms of accountability to Chinese users of information.

It is important to point out that there is a contested understanding of the establishment of the lóngmén zhàng. On the one hand, a body of indigenous Chinese interpretation exists which claims that the lóngmén zhàng was an early form of indigenous Chinese double-entry bookkeeping (Guo Daoyang, 1988). On the other hand, there is a relatively recent view that this claim represents somewhat of a myth (see, for example, Hoskin, Ma \& Macve, 2013). Although this study leans towards the view advocated by Gao Daoyang (1988), it is necessary to acknowledge that the assumption that the lóngmén zhàng was an early form of indigenous Chinese double-entry bookkeeping is open to question. In the context of the aims of this study, this 'east-west' debate does not in itself undermine the theory of alternative reporting models. Rather it opens up possibilities for different interpretations of the roots of the Traditional and Western reporting models.

Typically, transactions were recorded in the căoliú (caoliu, memorandum) using căomă (caoma, commercial) numerals, transferred them to the xìliú (xiliu, journal) using hàntǐ (haiti, standard) numerals and then posted them to the zŏngqing (zongqing, ledger) using kuàijì tǐ (kuaiji ti, accounting) numerals before preparing accounting reports (Gamble 1931; Huáng 1934; Fu 1989; Finegan 1978).

The direct influence of capitalist economic relations on the early Qing Dynasty served to maintain Chinese inherent double-entry bookkeeping through the lóngmén (longmen) account and the sìjiăo (sijiao) account. Under the Traditional reporting model, these accounts provided consistency between the double-entry bookkeeping principles and bookkeeping reports, infused the accounting process with classification and scientific rigour, and maintained the division of receipts and payments as well as assets and liabilities. These Traditional reporting model-bound Chinese accounts were grounded on scientific rule-making, and faithfully attempted to record property value elements and changes of property values. The principle of double-track settlement accounts also provided a technical checking role (Guō, 2011) through the adoption of the sìjiăo account. Here, the Chinese Zōngjié (Zongjie) took a similar shape to the Western balance sheet, while the Chinese Căijié (Caijie) looked very similar to the Western income statement. Accountability was maintained by the payment of guānlì dividends (guanli dividends, fixed rate of common stock) which ensured a form of cash 


\section{Shànghăi print media}

In reviewing the development of Shànghăi-based newspapers in the Qing Dynasty and its reporting of Chinese early companies reporting, it is beneficial to note the considerable influence of British newspapers on the Shànghăi-based media. British newspapers in the nineteenth century enjoyed considerable status as a form of mass communication which could influence politics, bring about social change and influence financial matters (Lee 2012; Michie 2011; Jones 1996). The Chinese print media during the late Qing Dynasty also had similar influences.

The ShēnBào (ShenBao) Newspaper, also known in English as The Shanghai News, founded by Ernest Major, an English businessman, commenced operations in 1872 in Shànghăi. The ShēnBào Newspaper was set up for a Chinese readership, run by Chinese compradors (native born agents in China) and editors in order to extract local community news and build up circulation and advertising connections with the local community. The ShēnBào Newspaper's relatively high circulation and advertising revenue ensured that the price of the paper was lower than that of its competitors. The ShēnBào Newspaper became influential in the Qīng Dynasty using innovative printing technology, the telegraph, and the báihuà (baihua, vernacular) to hold circulation and revenue.

Other newspapers in the Qing Dynasty included the English North China Herald, which was published in Shànghăi and featured translations of Chinese official notifications and news; the Shanghai Almanac, which was published by the North China Herald; the American-styled China Press; the English-language China Mail, which was founded in 1845 and run since 1872 by George Bain; and the Shanghai Mercury, an evening daily newspaper founded in 1879 . The North China Daily News, edited by Moberley Bell, a distinguished war correspondent, 'enjoyed a virtual monopoly of Shànghăi's advertising market, while presenting a stolidly imperial point of view in its editorial columns' (Thompson 2011, 141).

Higher literacy rates and densely packed populations in economically advanced areas allowed newspapers to question the complex bureaucratic structures of the Qing Dynasty (Lufrano 2013). Transitional moments in printed communications in China arose with the emergence of Chinese-language and English-language newspapers, thus opening up a readership to Chinese and foreign audiences (Mokros 2012; Mittler 2004). This shift provided incentives for companies to disclose information in newspapers. For example, HSBC's success in China came about from its ability to attract capital from both Chinese and foreign shareholders and to draw savings from depositors from all walks of life (Horesh 2006). 
The modern press, particularly those based in Shànghăi, introduced a new level of public awareness of Western practices (Rankin 2008).

...the emerging news media played a defining role, intensifying the sense of alarm at foreign incursions, increasing the anger aimed at the court's policies, and stimulating the simultaneous fascination for the foreign and exotic. (Rankin 2008, 40)

Editorialists encouraged industrial development, railed against official corruption, and urged Chinese readers to familiarise themselves with Westerners and their new technologies and education system (Wang 2007). The newspaper readership expanded to include people from commercial walks of life, such as professionals, entrepreneurs, shop clerks and small merchants (Wang 2007), reaching beyond the local to the national market (Wue 2004). Even, the collapse of the Qing Dynasty was watched closely by the commercial press and its readers (Wang 2007).

Given the different reporting models that existed in the Qing Dynasty, it is of considerable interest how the accountabilities of these early companies were presented by the news media during this period. As such, this study looks at the print media reporting of early Chinese companies from the middle period of the Qing Dynasty when the Opium War broke out in 1840 until the imperial monarchy's overthrow in the revolution of 1911.

\section{Print media reporting of the reporting by early Chinese companies}

As shown in Figure 1, a form of Western-narrow accountability was demonstrated by the written disclosure of shares and stocks in the North-China Herald, where prominence was given to details about paid-up capital, and the latest prices and dividends ratios (Wood 1866, 4). What is clear, in Figure 1, is not so much that the bank shares, denominated in pounds (rather than the taels of commercial companies), provided a significantly larger dividend return on investments than that offered by the commercial companies, but that a Western-narrow form of accountability was presented on the pages of the Shànghăi-based press for existing and prospective investor groups as well as a general readership. To our view, this presentation shows that the media facilitated a transmission of financial accounting information designed to address the commercial interests of a business readership. Public display of commercial information through accounting metrics served to enhance the milieu of accountability of these early companies of the Qing Dynasty.

\section{<Please Insert Figure 1 here>}


Western-narrow forms of accountability were not limited to lists of share prices and dividends. As revealed in Figure 2, some entities, such as the HSBC, disclosed their statements of assets and liabilities in the print media, in this case, the North China Daily News (Little 1869). Critically, the statements of assets and liabilities did not separate equity from liabilities, and paid-up capital and reserve fund were included in the liabilities side of the statement. Crucially, here was a demonstration of the fusion between Western-narrow and Traditional forms of reporting providing open accountability to a newspaper readership, an exposure that gave prominence to the activities of HSBC and the workings of technical accounting itself.

\section{$<$ Please Insert Figure 2 here $>$}

In keeping with the Traditional reporting model, this form of technical accounting was not confined to the English language. As shown in Figure 3, the Shànghăi Stock Quotation, was disclosed in detail in the Shanghai Daily News (Shànghăi Xīnbào, 1871). The Shànghăi Stock Quotation, expressed in Chinese, also placed great emphasis on the return of dividends, underlying the notion that Chinese, as well as foreign, sources of financing were sought by the Western companies in China. Consistent with the Traditional reporting model, accountabilities of entities gave deference to local language and customs. The first column of Figure 3 provides the name of the company listed for the Shànghăi Stock Quotation and the second column presents the capital in yuán (yuan) paid per share. Information about the amount of dividends (expressed in yuán and liăng (liang)) per 100 yuán of the company’s capital is shown in the third column of Figure 3. The last column depicts the current price per share of the company. Thus, for example, the France Gas Company Limited is listed as having paid-up capital share of 50 liăng, paying 8 liăng of dividends per 100 liăng of capital, and a current price of 60 liăng per share. The public display by the Shànghăi-based print media reports of these summarised financial ratios demonstrates a willingness by the print media to facilitate forms of both performance monitoring and stakeholder engagement. There is more than a hint of Gardella's (1992) 'sprouts of capitalism' here. There is, in this display, a distinct form of economic and financial accounting visibility of the precepts of the Western-narrow reporting model. ${ }^{2}$

\section{$<$ Please Insert Figure 3 here $>$}

Again, consistent with the Traditional reporting model, the presentation of accounts was not exclusively foreign in format. Figure 4 illustrates the Chinese formatting of HSBC financial information in the financial pages of the ShēnBào Newspaper in 1886 (Qián 1886, 4). Here we see how HSBC adopted a Traditional Chinese financial report format to target Chinese investors. Importantly, these Chinese financial reports show that HSBC reserved funds for future dividends as a form of monetised flow of information. Figure 4 presents an example of 
an HSBC declaration for the period January 1 to June 301886 , including monetary calculations of retained earnings, net income, dividends, and extensive details of cún and gāi accounts. For the Shànghăi-based print media readership, there is much in these accounts that provides information to analyse the current financial position of HSBC, particularly in comparing cun and gai, thus facilitating assessment of HSBC's financial position.

\section{$<$ Please Insert Figure 4 here $>$}

Clear evidence exists that, by Western-narrow and Traditional reporting model accountability benchmarks, unique forms of financial accountability developed during 1840-1911, particularly in meeting Chinese investors' appetite for dividends, which gave prominence to information flows about guānlì dividends through an "Accounts Summary". The China Merchants' Steam Navigation Company (CMSN) was a typical guāndū shāngbàn (guandu shangban, where officials supervised the operations of merchants) in the sense that officials controlled the company and prominence given to the Traditional reporting Zhàngluè that provided a summary of financial position. As a matter of accounting form, the Zhàngluè (1873-1911) consisted of four parts - rules and regulations (systems), narrative of the progress of the company's business operating activities and balance sheet - but there appeared to be no audit. CMSN also provided a Căijié (Caijie, income statement) (Jiāotōngbù Cáiwù Kuàijìjú,Zhōngguó Jiāotōng Kuàijì Xuéhuì 1994) ${ }^{3}$ but notably, accountability between board of directors and management was not given a narrative explanation. Perhaps most striking for the period was the fact that early Chinese companies, such as CMSN, attempted to maintain a particularly Chinese commercial form of accountability - guānlì dividends - both as a stream of income and as a source of monetised information.

\section{$<$ Please Insert Figure 5 here $>$}

As shown in Figure 5, this unique form of financial accountability is illustrated by the case of

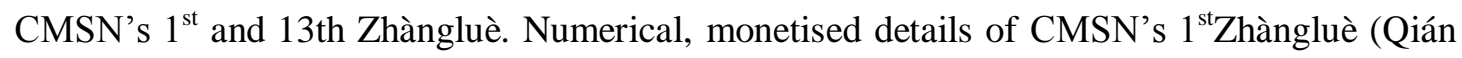
1874, 3-4) reveal that gǔfèn zīběn (gufen ziben, common stock) was valued at 476,000 liăng, guānlì dividends were valued at 47,600 liăng (liang) and accounted for ten per cent of gŭfèn zīběn. These forms of calculations and techniques were replicated by RénJìHé (RenJiHe) Insurance Company Limited which disclosed $6 \%$ guānlì dividends rate in its $1^{\text {st }}, 2^{\text {nd }}, 3^{\text {rd }}, 4^{\text {th }}$, $5^{\text {th }}$ and $7^{\text {th }}$ Zhàngluè from 1887 to 1893 . The China Merchants Bureau also disclosed a $6 \%$ guānlì dividends rate in its 1899 accounts summary. In a customary Western form of financial accountability, Figure 5 displays the position of CMSN's official debt, interest and accounts payable, as well as retained earnings. Items of gai are broken down by activity type and geographic area. CMSN's accounts provide newspaper readers the opportunity for an analysis 
of financial performance. There is a deference to the customs of the Traditional reporting model melded with a quest for Western stewardship reporting.

\section{$<$ Please Insert Figure 6 here $>$}

As depicted in Figure 6, CMSN's 13th Zhàngluè disclosed both guānlì (guanli) dividends and yúlì dividends (Qián 1887). It can be seen here that CMSN's gǔfèn zīběn was 2,000,000 liăng and half-year guānlì dividends were 120,000 liăng (liang). Importantly for users and readers of Zhàngluè information, these dividends were treated as expenses even before the depreciation and remuneration of directors and senior managers; if the firm had net income, it was possible to pay yúlì dividends (yuli dividends, which were a flexible or fixed rate of net income) to stockholders. The accounts themselves appear to bear a form of accountability of stewardship and entity. Formal sijiăo zhàng comprised cún to record stocks of assets and credits, gāi to record claims on assets, including capital and liabilities, jìn to record receipts of revenue and zhī to record payments of expenditure. Figure 5 shows cún and gāi suggesting that CMSN's $1^{\text {st }}$ Zhàngluè did not fully follow the rules of formal sìjiăo zhàng. However, Figure 6, which also depicts the Zōngjié and Căijié prepared by the sìjiăo zhàng (sijiao zhang, 'four-leg bookkeeping'), suggests that the CMSN's 13th Zhàngluè followed the rules of formal sìjiăo zhàng.

In a further example of the sustained accountability taking place in the Qing (Qing) Dynasty, Figure 7 shows CMSN's Constitution Regulations (Jiāotōngbù Cáiwù Kuàijì jú, Zhōngguó Jiāotōng Kuàijì Xuéhuì 1994). CMSN's constitution regulated that CMSN's fixed guānlì dividend rate was $10 \%$ of common stock. The fixed yúlì dividend rate was $80 \%$ of net income. $20 \%$ of net income was paid as remuneration for shāngzǒng and dǒngshì rén (shangzong and dongshi ren, directors and senior managers). However, in a sign of the times, there were no regulations on minimum levels of retained earnings. After a period of time, the excessive payment of dividends caused the CMSN's retained earnings to dip so substantially that in some cases, operating losses arose. For example, retained earnings in 1877 represented a loss of $-35,290.694$ liăng.

$<$ Please Insert Figure 7 here $>$

\section{Reflections of the accountability of early Chinese companies}

It appears that the Traditional reporting model was helpful in engendering accountabilities in early Chinese companies' of the Qing Dynasty. Through Chinese indigenous forms of technical accounting, common stock was treated similarly to debt, preferred stock and 
common stock; and free cash flow (FCF) was used as a basis to repay the debt principal, interest and dividends. Evidence also exists that early Chinese companies, such as CMSN, used FCF to pay guānlì dividends, yúlì dividends and interest as a financial reward for investors. Financial accounting information about these dividends and interest were meticulously recorded. A positive FCF seemingly allowed early Chinese companies to demonstrate in the Shànghăi-based print media a commercial form of accountability for future payments of these items.

Perhaps spurred on by the need for a greater sense of this unique accountability of listed companies, the Qing regime set up the Commercial Law office in 1903 and attempted to modernise the Chinese accounting system by assimilating Western bookkeeping techniques into private and public sector enterprises (Auyeung and Ivory 2003). From 1904 to 1907 a formal legal code for commerce and industry was enacted, including the General Rules for Merchants, Company Law, and laws on chambers of commerce, company registration, bankruptcy, patent rights, government awards and newspaper publications (Auyeung and Ivory 2003).

Figure 8 presents excerpts of the 1904 Gōngsī lǜ (Gongsi lv, Company Law). In 1904, Clause 110 of the Gōngsī lǜ regulated that companies could no longer use common stock capital to pay dividends. Clause 112 of the Gōngsī lǜ stipulated that twenty per cent of net income had to be reserved (Gōngsī Lü 1904).

\section{<Please Insert Figure 8 here $>$}

Importantly, however, early Chinese companies still paid guānlì dividends after the 1904 Gōngsī Lù̀. Noticeably, CMSN paid a 10\% guānlì dividend rate in 1904. The guānlì dividends rate of Chóngmíng (Chongming) Branch of Dàshēng (Dasheng) Spinner Company was struck at 8\%. Moreover, Màoxīn (Maoxin) Flour Factory founded by the Róng Déshēng (Rong Desheng) family disclosed a 10\% guānlì dividends rate in its 1904 New Shares Issue Declaration (Shànghăi Shèhuì Kēxuéyuàn Jīngjì Yánjiū Suǒ 1962). The Shāndōng Bóshān (Shangdong Boshen) Glass Company also disclosed a 5\% guānlì dividends rate in its 1904 New Shares Issue Declaration (The Prospectus) (Qián 1904), while the Sōngnèn Liăngjiāng (Songnen Liangjiang) Fishing Company declared 5\% guānlì dividends rate in 1907 when it issued new shares (Qián 1907).

During the initial ten years of CMSN's existence, the narrative of the progress of the company's business operating activities consisted of both annual operating activities and settling accounts in order for Hóngzhāng Lǐ (Hongzhang Li), who was Zhílì (Zhili) Governor (one of nine highest Fēngjiāng (Fengjiang) Ministers) and Běiyáng (Beiyang) Trade Minister, 
to be clearly informed of CMSN's financial situation (Jiāotōngbù Cáiwù Kuàijìjú, Zhōngguó Jiāotōng Kuàijì Xuéhuì, 1994). Here, then, we see the Traditional reporting model offering a specialised alternative form of accountability directed to a confined number of state bureaucrats.

These bureaucrats had much to say about early Chinese companies' operational matters. Guāndū shāngbàn companies were initially established and financed by state investment. State bureaucrats identified influential merchants to act as company operators to attract private capital. When the companies made profits, they were ordered to repay the state's loans and interest. For example, CMSN had gōngkuăn cún xiàng (gongkuan cun xiang, debts from the State) and gōngkuăn xī xiàng (gongkuan xi xiang, interest for the debts from the State) items in its first Zhàngluè in 1874 (Qián 1874). The interest rate on CMSN's debt was much lower than its overall dividend rate.

It appears creditors (mainly the government), who were satisfied with early Chinese company's accountability under the Traditional reporting model, were eager to facilitate commercial loans. However, the material operating power of these early companies was controlled by a few government officers, referred to in Chinese as the zǒngbàn (zongban), kuàibàn (kuaiban) and bāngbàn (bangban), assigned by the state bureaucracy. These government officers came from merchants and officials, and possessed the status of semi-official and semi-merchants. Thus, the companies' development was ultimately determined by the state bureaucrats, implementing the requirements of the ruling imperial government and political system, rather than those of the shareholders. Indeed, the management of these companies was imperial in nature. Established since 1872, CMSN, Kāipíng (Kaiping) Mining Bureau, Tiānjīn (Tianjin) Telegraph Administration, Shànghăi Machine Weaving Bureau were all run on traditional lines. These guāndū shāngbàn companies were protected by the bureaucrats but enjoyed Qing governmental privileges such as tax cuts, tax exemptions, loans, interest relief and patents. These privileges facilitate increased intervention in the operating processes of the companies by the state bureaucrats (Zhōngguó Qǐyèshǐ Biānjí Wěiyuánhuì, 2004).

From 1901 to 1911, China had established 386 modern industrial enterprises, with aggregated capital exceeding 880 million yuan (Zhāng 2001), that at times represented an uneven commercial playing field. For example, one of these industrial enterprises, Dàshēng (Dasheng) Spinner Company, was a large private textile company. In 1898, it ran spinning machines financed by the Húběi (Hubei) Government Spinner Bureau. The company repaid state interest annually, but was not liable to the state for any potential profits and losses generated. Another early Chinese company Dàshēng Spinner Company was registered as a shēnlı̌ng shāngbàn (shenling shangban, which were firms led by gentlemen who left official positions) 
with approval from the Shāng (Shang) Bureau of the Qīng (Qing) government. In effect, Dàshēng (Dasheng) Spinner Company received a monopoly on the spinning franchise for 20 years (Zhāng, 1931) despite preparing Chinese-style Shuōluè (Shuolue, which were words description of the firms' situation) and Zhàngluè from 1900 to 1909 (Zhāng Jiăn (Zhang Jian) Research Center, Nántōng (Nantong) City Library 1994) to account for its operations.

Elements of Western-broad reporting may also have been present in the early Chinese companies of the Qing Dynasty with the performance of social responsibility through donations to victims of natural disasters. The First Accounts Summary of CMSN showed that CMSN donated 2,139 liang 4 qian 9 fen $3 \mathrm{li}$ in aidfor natural disasters in the Jin district.

\section{Conclusion}

The print media showcased different forms of accountability maintained by a fusion of Western-narrow and Traditional reporting models. Chinese financial accountability was particularly strengthened by the firms' positive FCF to guarantee the repayment of principal, interest and dividends. Although the 1904 Gōngsī lü placed a particular emphasis on Western accountability benchmarks, Chinese reporting practices prevailed, suggesting that although Chinese and Western reporting models were distinguishable in form, much in their accountabilities was similar in substance.

The preservation of Chinese forms of reporting by early companies of the Qing Dynasty allowed companies to demonstrate their respect for expectations of local stewardship. Gardella (1982) raised the notion that it was important for Chinese commercial enterprises to observe a pattern of traditional obligations and patriarchal authority in the Qing Dynasty. Maintaining traditional forms of reporting fitted in with this practice. Yet it appeared that it was the Western signs of accountability of early Chinese companies that informed the reports of the Shànghăi-based print media. Thus, prominence was given to media coverage of dividend yields, current price per share and various forms of stock quotations. Accounting summaries of zongjie (balance sheets) and caijie (income statements) provided a media readership with a snapshot of the calculation of profitable exchange.

In a city which experienced rapid change and great upheaval, Shànghăi-based newspapers presented a singular form of communication about early Chinese companies' financial performance. The financially-bound precepts of Anglo-Saxon newspapers, which rippled across to British- and American-owned Chinese papers, energised Chinese-listed companies as centres of commerce and Chinese banks as centres of credit. The presentation of Western and Chinese benchmarks of accountability expressed in metrics and key financial ratios on the pages of the Shanghai-based press added vitality to Chinese accounting. In the late Qing 
Dynasty, this vitality saw rapid changes in the Chinese accounting system, alongside an introduction of formal legal codes for commerce and industry and enactments in newspaper publications themselves.

The accountability mechanisms raised by the use of both Traditional and Western-narrow forms of reporting models attempted more than simply to measure and communicate information. Through the Shànghăi-based newspapers, their virtues laid in offering multitudinous financial stories about early Chinese companies to the varied readership interested in the financial accounting information for decision making. It is also clear that these accountability mechanisms of the Traditional reporting model may have been useful for state bureaucrats for critical decision making during the late Qīng Dynasty.

\section{Acknowledgement}

We would like to thank two anonymous referees and the editor for their very helpful advice on the paper.

\section{References}

Aiken, M., and W. Lu. 1993a. "Chinese Government Accounting: Historical Perspective and Current Practice." The British Accounting Review 25 (2): 109-129.

Aiken, M., and W. Lu. 1993b. "Perception, Culture and Research Method in Accounting History: Its Evolution in Modern China.” Accounting History 5 (1): 11-20.

Aiken, M., and W. Lu. 1993c. "Historical Instances of Innovative Accounting Practices in the Chinese Dynasties and Beyond." Accounting Historians Journal 20 (2): 163-186.

Aiken, M., and W. Lu. 1998. "The Evolution of Bookkeeping in China: Integrating Historical Trends with Western Influences.” Abacus 34 (2): 220-242.

Auyeung, P., and P. Ivory. 2003. "A Weberian Model Applied to the Study of Accounting Stagnation in Late Qing China.” Accounting, Business \& Financial History 13 (1): 5-26.

Brown, A. M., and G. Tower. 2002. "Traditional and Western Accounting Disclosure Models for Pacific Island Countries' Entities.” Pacific Accounting Review 14 (1): 43-66.

Brown, A. M. 2011. "The Milieu of Government Reporting in Vanuatu." Pacific Accounting Review 23 (2): 165-184. 
Chen, R. S. 1975. "Social and Financial Stewardship.” The Accounting Review 50 (3): 533-543.

Chén, ZhìWǔ (Chen, Zhiwu). 2010. Jinnróng dě Luójí(Jinrong de Luoji, Financial Logic). Běijīng (Beijing): Guójì Wénhuà Chūbăn Gōngsī (Guoji Wenhua Chuban Gongsi, International Culture Publishing Company).

Finegan, M.H. 1978. "Merchant Activities and Business Practices as Revealed in Several Manuscripts from Fukien." Qing History Inquiry 3: 76-90.

Fu, P. 1971. "Government Accounting in China during the Chou Dynasty (1122 B.C. - 256 B.C.)." Journal of Accounting Research 9 (1):40-51.

Fu, J. 1989. “An Outline of Popular Double-Entry Accounting in the Qing.” Chinese Economic History Research 3: 73-77.

Gamble, S.D. 1931. The Household Accounts of Two Chinese Families. New York: China Institute in America.

Gardella, R.P. 1982. "Commercial Bookkeeping in Ching China and the West: A Preliminary Assessment." Qing History Research 3: 56-72.

Gardella, R. 1992. "Commercial Bookkeeping Methods and Capitalist Rationalism in Late Qing and Republican China.” The Journal of Asian Studies 51(2): 317-339.

Gōngsī Lù (Gongsi lv, Company law) 1904. “Gōngsī Lǜ Dōngfāng Zázhì (Dongfang Zazhi, Dongfang Journal) 1 (1): 213-232.

Guō, Dàoyáng (Guo, Daoyang). 1988a. Zhōngguó Kuàijì Shǐgăo (Zhonguo Kuaiji Shigao, China Accounting History Draft). Běijīng (Beijing): Zhōngguó Cáizhèng Jīngjì Chūbănshè (Zhongguo Caizheng Jingji Chubanshe, China Financial and Economic Publishing House). Xiàcè (Xiace, Volume 2)

Guō, Dàoyáng (Guo, Daoyang).1988b Shilùn Zhōngguó Kuàijì dě Lìshǐ Gòngxiàn (Shilun Zhongguo Kuaiji de Lishi Gongxian, The Historical Contributions of Chinese Accounting), Collected Papers of the Fifth World Congress of Accounting Historians, The University of Sydney. Guō Dàoyáng Wénjí (Guo Daoyang Wenji,Guō Dàoyáng Collected Works). Běijīng (Beijing): Jīngjì Kēxué Chūbănshè (Jingji Kexue Chuban she, Economics Science Press).2009 the first edition: 543-548.

Guo, Daoyang, Jialin Xu, Jun Kang, Lan Peng, and Jinxiu Zhang. 2011. A Global History of Accounting, Financial Reporting and Public Policy: Asia and Oceania. Studies in the 
Development of Accounting Thought. London: Emerald Group Publishing Limited. Volume $14 \mathrm{C}$.

Horesh, N. 2006. "Printed in London, Disbursed on the Bund: The Hongkong Bank and Its Early Note Issue in Shanghai, 1865-1911.” Late Imperial China 27(1) (June): 109-140.

Hoskin, K. W., D. Ma, and R.H. Macve. 2013. “A Genealogy of Myths about the Rationality of Accounting in the West and in the East". SSRN Working Paper,

http://ssrn.com/abstract=2389309

Hsu, T.F. 1991. "Traditional Chinese Bookkeeping Methodology.” Chinese Business History. 2: $1-2$.

Huáng, Y.P. 1934. An Examination of Traditional Commercial and Industrial Accounting in Guăngdōng.Guăngzhōu: Bureau of Economic Research, National Sūn Yat Sēn University.

Jiāotōngbù Cáiwù Kuàijìú, Zhōngguó Jiāotōng Kuàijì Xuéhuì (Jiaotongbu Caiwu Kuaijiju, Zhongguo Jiaotong Kuaiji Xuehui, Finance Accounting Bureau under Ministry of Transportation, China Accounting Society of Transportation). 1994. Zhāoshāngjú Kuàijìshǔ (Zhaoshangju Kuaijishi,Accounting History of the China Merchants'Steam Navigation Company). Shànghăi (Shanghai): Rénmín Jiāotōng Chūbănshè (Remin Jiaotong Chubanshe, Renmin Transportation Press).

Jones, A. 1996. Powers of The Press: Newspapers, Power, and the Public in Nineteenth Century England. London: Scholars Press.

Lee, T. A. 2012. "A Helpless Class of Shareholder': Newspapers and the City of Glasgow Bank Failure." Accounting History Review 22 (2): 143-159.

Lin, Z.J. 1992. "Chinese Double-Entry Bookkeeping Before the Nineteenth Century." The Accounting Historians Journal 19 (2): 103-122.

Little, E.S.(Ed). 1869. “Hongkong and Shanghai Bank.” North China Daily News. 2(17): 3.

Lufrano, R. 2013. "Minding the Minders: Overseeing the Brokerage System in Qing China." Late Imperial China, 34 (1) June: 67-107.

Michie, R. 2011. Gamblers, Fools, Victims, or Wizards: The British Investor in the Public Mind, 1850-1930. In Men, Women and Money: Perspectives on Gender, Wealth, and Investment, 1850-1930, edited by D.R. Green, A. Owens, J. Maltby, and J. Rutterford, 156183. Oxford: Oxford University Press. 
Mittler, B. 2004. A Newspaper For China?: Power, Identity, and Change in Shanghai's News Media, 1872-1912. Cambridge, Mass.: Harvard University Press.

Mokros, E. 2012. "Reconstructing the Imperial Retreat: Politics, Communications, and the Yuanming Yuan under the Tongzhi Emperor, 1873-4.” Late Imperial China 33(2) December: 76-118.

Qián,Xīnbó (Qian,Xinbo).(Ed).1874.Zhāoshāng Lúnchuánjú Zhàngluè(Zhaoshang Lunchuanju Zhanglue, The First Accounts Summary of CMSN).1874. ShènBào (ShenBao) Newspaper. 9 (12): 3-4

Qián, Xīnbó (Qian,Xinbo). (Ed).1886. “Huìfēng Yínháng Gàobái(Huifeng Yinhang Gaobai,HongKong and Shanghai Banking Corporation Disclosure)." ShēnBào (ShenBao) Newspaper 8 (18):4

Qián,Xīnbó (Qian,Xinbo).(Ed). 1887. “Jiēlù Lúnchuán Zhāoshāngjú Dìshísānjiè Zhàngluè (The $13^{\text {th }}$ Accounts Summary of CMSN)." ShēnBào (ShenBao) Newspaper. 4 (1): appendix

Qián, Xīnbó (Qian,Xinbo). (Ed). 1904. "Shāndōng Bóshān Bōlí Gōngsī Zhāogǔ(Shandong Boshan Boli Gongsi Zhaogu, The Prospectus of Shandong Boshan Glass Company)." ShēnBào (ShenBao) Newspaper. 5(13): appendix.

Qián, Xīnbó (Qian,Xinbo).(Ed). 1907. "Yúyè Gōngsī Zhāogǔ Xiángzhì (Yuye Gongsi Zhaogu Xiangzhi,The Prospectus of Songnen Liangjiang Fishing Company)." ShēnBào (ShenBao) Newspaper 6 (5): 12.

Rankin, M. B. 2008. “Alarming Crises/Enticing Possibilities: Political and Cultural Changes in Late Nineteenth-Century China." Late Imperial China 29 (1): 40-63.

Shànghăi Shèhuì Kēxuéyuàn Jīngjì Yánjiū Suǒ (Shanghai Shehui Kexueyuan Jingii Yanjiu Suo, Shanghai Academy of Social Sciences Institute of Economic Research Economic History Group).1962. Róngjiā Qǔyè Shĭliào (Rongjia Qiye Shiliao, Rong Family Enterprise Historical Data). Shànghăi (Shanghai): Shànghăi Rénmín Chūbănshè (Shanghai Renmin Chubanshe, Shanghai Renmin Press) 10: 15.

Shànghăi Xīnbào. 1871. "Shànghăi Gǔfèn Hángqíngzhǐ (Shanghai Gufen Hangqingzhi, Shanghai Stock Quotation).” Shànghăi Xīnbào (Shanghai Xinbao, Shanghai Daily News) 3(14): 1. 
Shuài,Tiānlóng(Shuai,Tianlong).2001. Qīng mò dě Shāngshì Lifă(Qing mo de Shangshi Lifa,The Late Qing Dynasty Commercial Legislation).Shāngfă Yánjiū(Shangfa Yanjiu, Commercial Codes Studies).Běijīnng(Beijing):Rénmín Fǎyuàn Chūbǎnshè(Renmin Fayuan Chubanshe,People's Court Press).Dìyìjí(Diyiji,the first series).

Sūn, Jiànhuá (Sun, Jianhua). 2008. Jìndài Zhōngguó Jīnróng Fāzhăn yǔ Zhìdù

Biànqiān(Jindai Zhongguo Jinrong Fazhan yu Zhidu Bianqian,Modern China's Financial Developments and Systems Change)(1840-1945). Běijīng (Beijing): Zhōngguó Cáizhèng Jīngjì Chūbănshè (Zhongguo Caizheng Jingji Chubanshe, China Financial and Economic Publishing House).

Thompson, P. 2011. Shanghai Fury: Australian Heroes of Revolutionary China. Sydney: William Heinemann.

Wang, J. 2007. “Officialdom Unmasked: Shanghai Tabloid Press, 1897-1911.” Late Imperial China.28 (2) (December): 81-128.

Wood, M.F (Ed.) 1866. "Monetary and Commercial (Shares and Stocks)." North-China Herald 6(23):4

Wue, R. 2004. "The Profits of Philanthropy: Relief Aid, Shenbao, and The Art World in Later-nineteenth Century Shanghai.” Late Imperial China 25(1) June: 187-211.

Yáo, Zhòngbó (Yao,Zhongbo), Yùsūn Xú (Yusun Xu), Xīnóng Zhū (Xinong Zhu), Xiăomíng Féng (Xiaoming Feng), and Jìnrú Yuán (jinru Yuan). (Ed). 1919. Shànghăi Wàishāng Zhèngquàn Jiāoyìsuǒ Zhī Luèshǐ (Shanghai Waishang Zhengquan Jiaoyisuo Zhi Lueshi,A Brief History of Shanghai Western Stock Exchange). 1919-09-16. Yinháng Zhōubào (Yinhang Zhoubao, Bank Weekly). Volume 3. No. 34: 37-41.

Zhāng, Cūntíng (Zhang, Cunting). 2001. Zhōngguó Zhèngquàn Shìchăng Fāzhăn Jiănshǐ -Qīngcháo Wănqī (Zhongguo Zhengquan Shichang Fazhan Jianshi-Qingchao Wanqi, A Brief History of China's Securities Market-Late Qing Dynasty). Zhèngquàn Shìchăng

Dăobào(Zhengquan Shichang Daobao, Securities Market Herald) 4: 37-40.

Zhāng, Jiăn (Zhang, Jian). 1931. Zhāngjìzǐ Jiǔlù (Zhangjizi Jiulu, ZhangJizi Nine Records). Shànghăi (Shanghai): Zhōnghuá Shūjú (Zhonghua Shuju, Zhōnghuá Book Press).

Zhāng Jiăn (Zhang, Jian) Research Center, Nántōng (Nantong) City Library. 1994. Zhāngjiăn Quánjí(Zhangjian Quanji,Complete Collections Works of Zhang Jian). Nánjīng (Nanjing): Jiāngsū(Jiangsu) Ancient Press, Dōngsū (Dongsu) Ancient Press. 
Zhào, Lánliàng (Zhao, Lanliang). 2003. Jindài Shànghăi Băoxiăn Shìchăng Yánjiū(Jindao Shanghai Baoxian Shichang Yanjiu,Modern Shanghai Insurance Market Research) (1843-1937). Shànghăi (Shanghai): Fúdàn Dàxué Chūbănshè (Fudan Daxue Chubanshe, Fudan University Press).

Zhao, Y.L. 1987. "A Brief History of Accounting and Auditing in China." In Accounting and Auditing in the People's Republic of China: A Review of Its Practices, Systems, Education and Developments, edited by E.Y. Lou, S. N. Wang, and A.J.H. Enthoven,.91-165, Joint Research Study by the Shanghai University of Finance and Economics and the Centre for International Accounting Development, The University of Texas at Dallas,.

Zhào, Yǒuliáng (Zhao,Youliang). 1992. Zhōngguó Gǔdài Kuàijì Shěnjì Shǐ (Zhongguo Gudai Kuaiji Shenji Shi, Accounting and Auditing History of Ancient China). Shànghăi (Shanghai): Lìxìn Kuàijì Chūbănshè (Lixin Kuaiji Chubanshe, Lixin Accounting Books Press).

Zhōngguó Qǐyèshǐ Biānjí Wěiyuánhuì (Zhongguo Qiyeshi Bianji Weiyuanhui, Editorial Board of the History of Chinese Enterprises). 2004. Zhōngguó Q̌̌yèshǐ (Zhongguo Qiyeshi,History of Chinese Enterprises). Běijīng (Beijing): Qǐyè Guănlǐ Chūbănshè (Qiye Guanli Chubanshe, Enterprise Management Publishing House).

\footnotetext{
${ }^{1}$ Although records of share trading is recognised by Sūn (2008), we have found no actual evidence of this trading.

${ }^{2}$ An English translation of Figure 3, together with translations of Figures 4 to 8, are presented in Appendix 1.

${ }^{3}$ The first to the $55^{\text {th }}$ Zhàngluè of CMSN followed 12 important rules and regulations (systems): approved CMSN stocks issuance constitution (notice, manual), regulations for CMSN, regulations for warehouses, regulations for steamships, constitutions for CMSN administration, regulations for navigation letters, export charters, consulting and instructions for stockholders reporting stock certificates loss, approval for charter of stock certificates losses, preface of board of directors of CMSN, stock certificate losses constitution (Jiāotōngbù Cáiwù Kuàijìjú, Zhōngguó Jiāotōng Kuàijì Xuéhuì, 1994).
} 


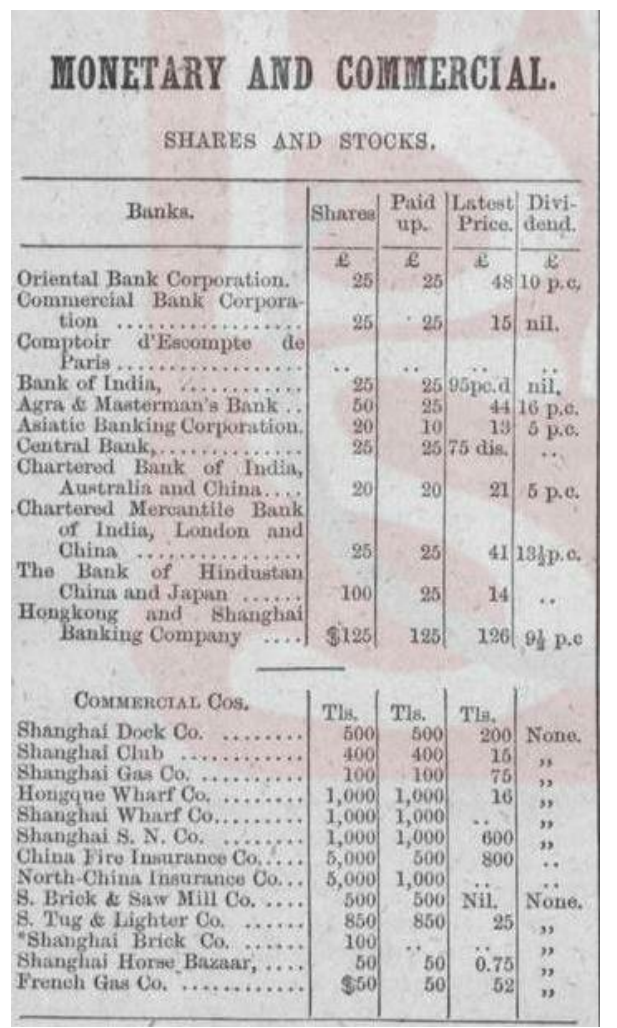

Figure 1. The early signs and stewardship of Western accountability

Source: Wood $(1866,4)$. 


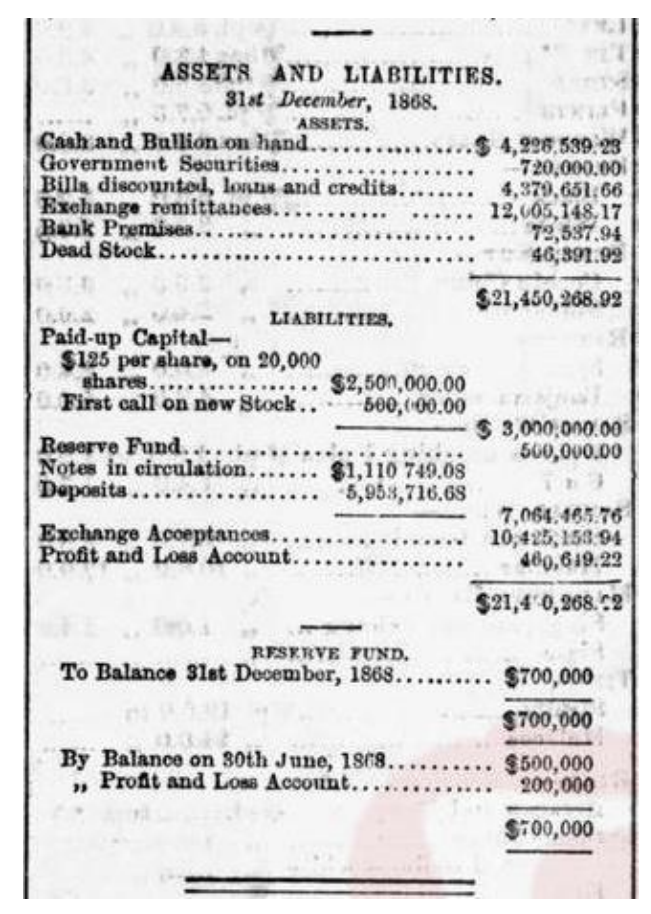

Figure 2. Further evidence of Western accountability

Source: Little $(1869,3)$ 


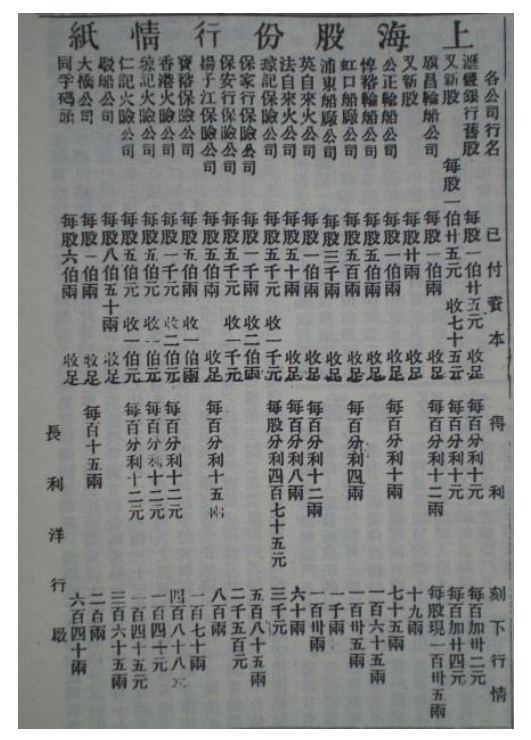

Figure 3. Shanghai stock quotation

Source: Shànghăi Xīnbào $(1871,1)$ 


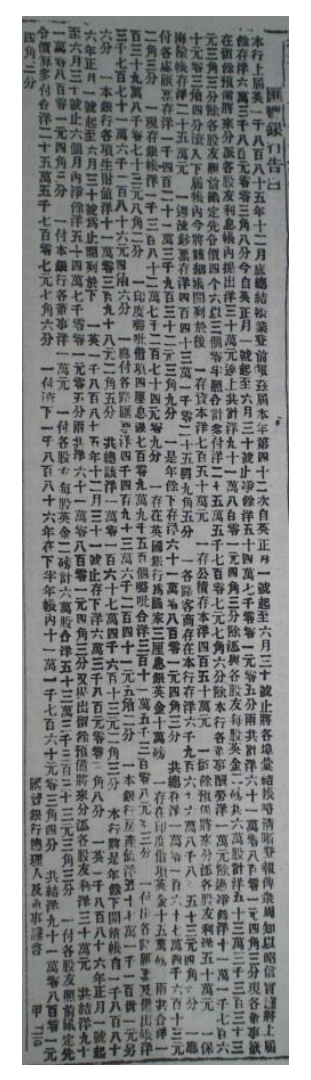

Figure 4. HSBC financial information disclosure in Chinese format

Source: Qián $(1886,4)$ 


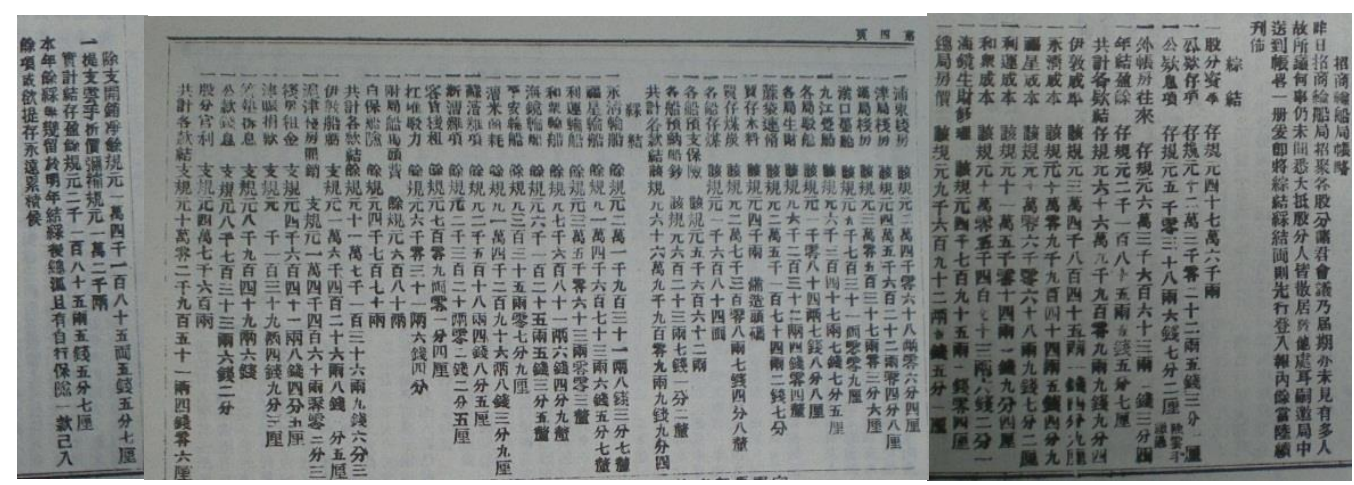

Figure 5. Early indications of Chinese companies' accountability

Source: Qián (1874, 3-4) 


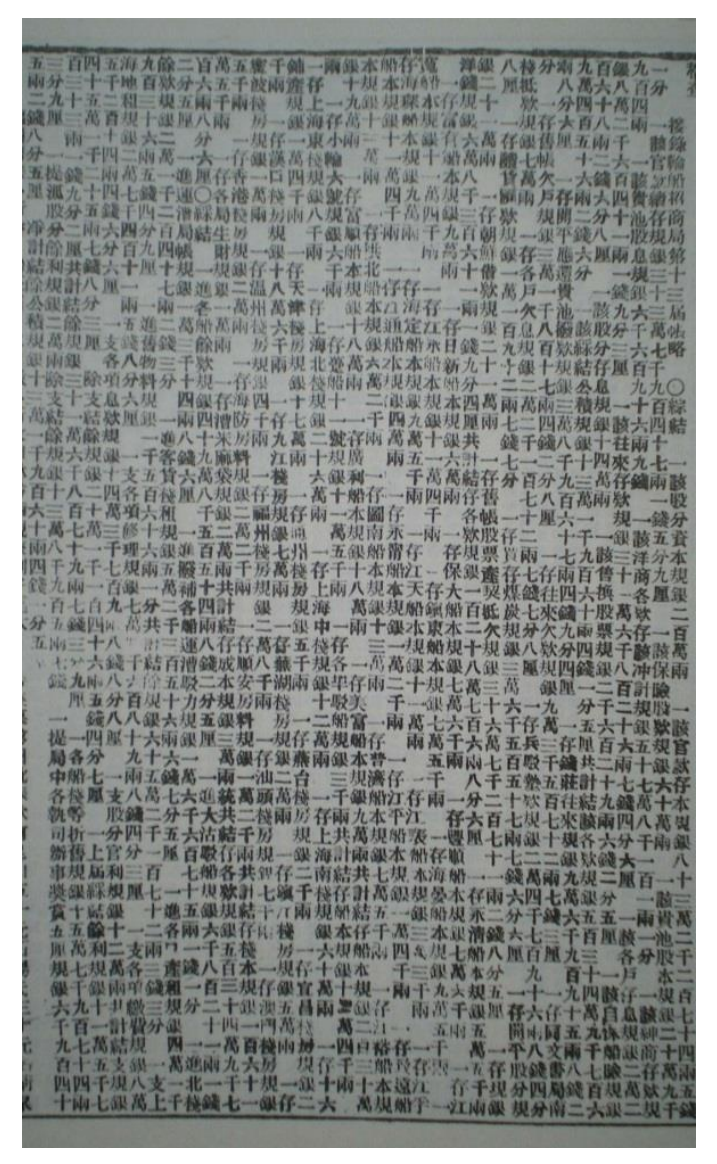

Figure 6. A further example of an 'accounts summary'

Source: Qián (1887, appendix) 
局内需用經费擬酌定数目以示限制也事先撙節斷難經久兹擬 局内商總董事人等年中辛工饭食以及紙張雜用擬於輪船運鋉覧載 水脚之内每百兩提出五兩以作局内前項經费其栈内經况則酸將耗 米開支船内經费則將所定船内月费開支統俟年終核計一年所得水 脚銀兩除每百兩提出經要五兩又照各股本銀每百兩提去利銀十兩 之外如有盈餘以八成㩲歸各股作爲滥利以二成分與商總董事人等 作爲花紅以示鼓㔘其分派花紅之處隨時公同核議

\section{Figure 7. Part of CMSN's constitution regulations}

Source: Jiāotōngbù Cáiwù Kuàijìjú, Zhōngguó Jiāotōng Kuàijì Xuéhuì (1994) 


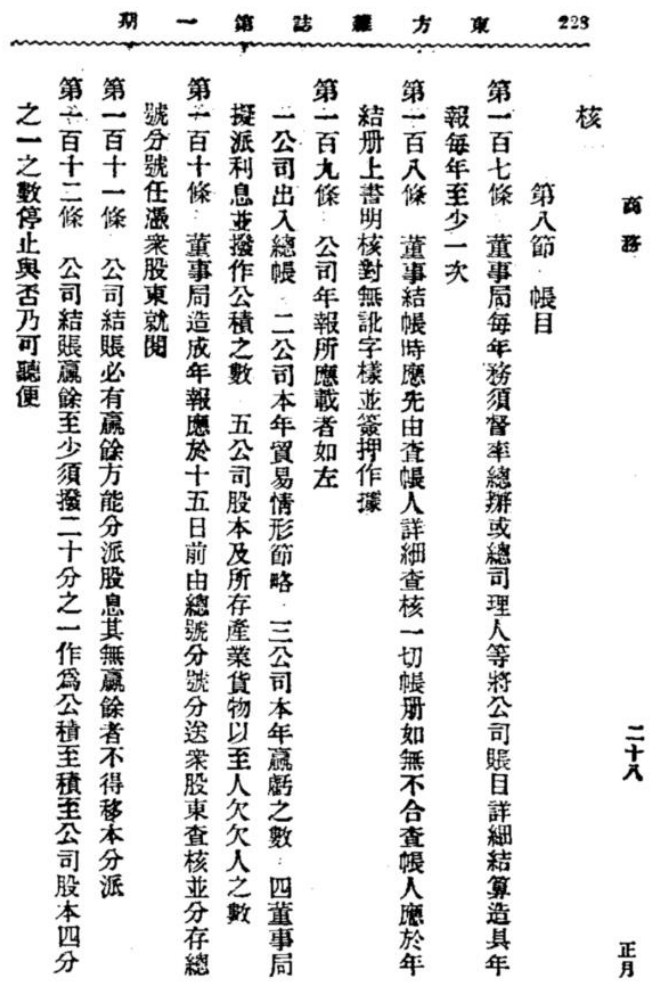

Figure 8. Part of Gōngsī Lù̀ (Gongsi lv, 1904 Company law)

Source: Gōngsī Lù̀ (1904, 213-232) 


\section{Appendix 1 - An English translation of figures 3 to 8}

This appendix provides an English translation of Figures 3 to 8 of the main text of the study.

A translation of Figure 3 below shows an excerpt from a newspaper of key financial information about companies listed on the Shanghai Stock Exchange.

Shanghai Stock Quotation

\begin{tabular}{|c|c|c|c|}
\hline Name & $\begin{array}{l}\text { Capital paid } \\
\text { per share }\end{array}$ & Dividends & $\begin{array}{c}\text { Current price } \\
\text { per share }\end{array}$ \\
\hline HSBC old shares & 125 yuan paid & $\begin{array}{l}10 \text { yuan dividends per } \\
100 \text { yuan capital }\end{array}$ & 132 yuan \\
\hline HSBC new shares & $\begin{array}{l}75 \text { yuan paid, } \\
50 \text { yuan payable }\end{array}$ & $\begin{array}{l}10 \text { yuan dividends per } \\
100 \text { yuan capital }\end{array}$ & 124 yuan \\
\hline $\begin{array}{l}\text { Shanghai Steamship Navigation } \\
\text { Co. (US) }\end{array}$ & 100 liang paid & $\begin{array}{l}12 \text { liang dividends per } \\
100 \text { liang capital }\end{array}$ & 135 liang \\
\hline $\begin{array}{l}\text { Shanghai Steamship Navigation } \\
\text { Co. new shares (US) }\end{array}$ & 20 liang paid & & 19 liang \\
\hline Union S. N. Co. (British) & 100 liang paid & $\begin{array}{l}10 \text { liang dividends per } \\
100 \text { liang capitals }\end{array}$ & 75 liang \\
\hline $\begin{array}{l}\begin{array}{l}\text { Dunyu Steamship } \\
\text { (British) }\end{array} \\
\end{array}$ & 500 liang paid & & 165 liang \\
\hline $\begin{array}{l}\begin{array}{l}\text { Hongkou } \\
\text { (British) }\end{array} \\
\end{array}$ & 500 liang paid & $\begin{array}{l}4 \text { liang dividends per } \\
100 \text { liang capital }\end{array}$ & 135 liang \\
\hline $\begin{array}{lll}\begin{array}{l}\text { Pudong } \\
\text { (British) }\end{array} & \text { Shipyard } & \text { Company } \\
\end{array}$ & 3,000 liang paid & & 1,000 liang \\
\hline $\begin{array}{l}\text { British Shanghai Gas Company } \\
\text { Limited }\end{array}$ & 100 liang paid & $\begin{array}{l}12 \text { liang dividends per } \\
100 \text { liang capital }\end{array}$ & 130 liang \\
\hline France Gas Company Limited & 50 liang paid & $\begin{array}{l}8 \text { liang dividends per } \\
100 \text { liang capital }\end{array}$ & 60 liang \\
\hline $\begin{array}{l}\text { Qiongji Insurance company } \\
\text { (US) }\end{array}$ & $\begin{array}{c}\text { 1,000 yuan paid, } \\
\text { 4,000 yuan payable }\end{array}$ & 475 yuan per share & 3,000 yиan \\
\hline $\begin{array}{l}\text { North-China Insurance Co. Ltd. } \\
\text { (British) }\end{array}$ & $\begin{array}{l}200 \text { liang paid, } \\
800 \text { liang payable }\end{array}$ & & 585 liang \\
\hline $\begin{array}{l}\text { The Union Insurance Society of } \\
\text { Canton (British) }\end{array}$ & $\begin{array}{c}\text { 1,000 yuan paid, } \\
\text { 4,000 yuan payable }\end{array}$ & & 2,500 yuan \\
\hline $\begin{array}{l}\text { Yangtsze Insurance Association } \\
\text { (US) }\end{array}$ & 500 liang paid & $\begin{array}{l}15 \text { liang dividends per } \\
100 \text { liang capital }\end{array}$ & 800 liang \\
\hline $\begin{array}{l}\text { China and Japan Marine } \\
\text { Insurance Co. }\end{array}$ & $\begin{array}{l}100 \text { liang paid, } \\
400 \text { liang payable }\end{array}$ & & 170 liang \\
\hline $\begin{array}{lll}\text { Hongkong Fire } & \text { Insurance } \\
\text { Company } & & \\
\end{array}$ & $\begin{array}{l}200 \text { yuan paid, } \\
800 \text { yuan payable }\end{array}$ & $\begin{array}{l}12 \text { yuan dividends per } \\
100 \text { yuan capital }\end{array}$ & 488 yuan \\
\hline Victoria Insurance Co. & $\begin{array}{l}100 \text { yuan paid, } \\
400 \text { yuan payable }\end{array}$ & $\begin{array}{l}12 \text { yuan dividends per } \\
100 \text { yuan capital }\end{array}$ & 140 yиап \\
\hline North British & 100 yuan paid, & 12 yuan dividends per & 145 yuan \\
\hline
\end{tabular}




\begin{tabular}{|l|c|l|c|}
\hline $\begin{array}{l}\text { Insurance Co. Far Eastern } \\
\text { Branch }\end{array}$ & 400 yuan payable & 100 yuan capital & \\
\hline Barge Company (British) & 850 liang paid & & 365 liang \\
\hline Bridge Company & 100 liang paid & $\begin{array}{l}\text { 15 liang dividends per } \\
100 \text { liang capital }\end{array}$ & 200 liang \\
\hline Olyphant Whard Co. & 600 liang paid & & 640 liang \\
\hline
\end{tabular}

Figure 3. Shanghai stock quotation

Source: Shànghăi Xīnbào $(1871,1)$

Figure 4 presents the Chinese format of an accounts summary of a listed British company.

\section{HSBC Declaration}

This declaration mainly disclosed the $42^{\text {nd }}$ accounts summary from January 1 to June 30,1886 .

Last retained earnings

Net income (01/01/1886-30/06/1886)

63,800 yuan 3 jiao 8 fen

Total net income

Withdrawal from cash for future dividends (interest) accounts

547,001 yuan 5 fen

Total

Dividends (60,000 shares) 2 pound per share

610,801 yuan 4 jiao 3 fen

300,000 yиап

910,801 yuan 4 jiao 3 fen

533,333 yиan 3 jiao 3 fen

Dividends premium considering the exchange

255,707 yuan 7 jiao 6 fen

10,000 yиan

Directors' remuneration

Retained earnings

111,760 yuan 3 jiao 4 fen

Cun Capital

Cun Additional paid-in capital (Reserve)

Cun Future dividends (interests) preparations for stockholders

7,500,000 yиan

4,500,000 yuan

500,000 yиan

Cun Marine insurance accounts

250,000 yиan

Cun Cash for one week turnaround

4,431,025 yuan 9 jiao 5 fen

Cun Merchants deposits

$69,668,853$ yuan 4 jiao 6 fen

Cun Bills payable

Cun Total net income

14,213,932 yuan 3 jiao 9 fen

610,801 yиan 4 jiao 3 fen

Total Cun

101,674,613 yuan 2 jiao 3 fen

Gai Cash (silver)

13,827,274 yuan 9 fen

Gai British national bonds (3\% rate) 100,000.00 pounds

Gai Loans from India 150,000.00 pounds

Gai Above two items exchanged into

1,398,073 yиan 8 jiao 2 fen

Gai India Rupee loans (4\% rate) 7,099,500.00 Rupee=

$3,115,308$ yuan 3 fen

Gai Bills and loans

37,716,186 yиan 4 jiao 6 fen

Gai Bills receivable

44,936,241 yuan 5 jiao 2 fen

Gai Buildings

571,131 yuan 6 fen

Gai Investments

110,398 yиan 2 jiao 5 fen

Total Gai

101,674,613 yuan 2 jiao 3 fen

HSBC General manager and Directors declared

Figure 4. HSBC financial information disclosure in Chinese format 
Source: Qián $(1886,4)$

Note:

$1 \mathrm{Cun}$ (to record liabilities and equity), Gai (to record assets and credits)

2 Money unit: 1 yuan $=10$ jiao $=100 \mathrm{fen}$

The CMSN's balance sheet and income statement are shown in Figure 5.

\section{The First Accounts Summary of CMSN}

\section{Zongjie (Balance Sheet)}

Capitals

Official debts

Official interests

Current accounts (Accounts payable)

Retained earnings

Total Cun

Yidun steamship costs

Yongqing steamship costs

Fuxing steamship costs

Liyun steamship costs

Hezong steamship costs

Haijin steamship investments repair

Headquarters Buildings

Pudong warehouse

Jinju warehouse

Hankou warehouse

Hankou barge

Jiujiang barges

Subsidiaries barges

Subsidiaries investments

Sacks

Timbers

Coals

Coals of various steamships

Advance insurances of various steamships

Prepayments of various steamships

Total Gai
Cun 476,000 liang

Cun 123,022 liang 5 qian 3 fen $11 i$

Cun 5,038 liang 6 qian 7 fen 2 li

Cun 63,663 liang 2 qian 3 fen 4 li

Cun 2,185 liang 5 qian 5 fen 7 li

Cun 669,909 liang 9 qian 9 fen 4 li

Gai 34,845 liang 1 qian 4 fen 9 li

Gai 109,944 liang 5 qian 4 fen 9 li

Gai 106,068 liang 9 qian 7 fen 2 li

Gai 115,014 liang 1 qian 9 fen $4 \mathrm{li}$

Gai 105,473 liang 6 qian 2 fen 1 li

Gai 4,795 liang 1 qian $4 \mathrm{li}$

Gai 9,692 liang 5 qian 5 fen 1 li

Gai 24,068 liang 6 fen 4 li

Gai 45,622 liang 4 fen 8 li

Gai 30,537 liang 3 fen $6 \mathrm{li}$

Gai 9,731 liang 9 li

Gai 6,347 liang 7 qian 7 fen $5 \mathrm{li}$

Gai 1,084 liang 7 qian 8 fen 8 li

Gai 6,232 liang 4 qian 4 li

Gai 25,174 liang 2 qian 7 fen

Gai 4,000 liang

Gai 27,308 liang 7 qian 4 fen 8 li

Gai 1,684 liang

Gai 5,662 liang

Gai 623 liang 7 qian 1 fen 2 li

Gai 669,909 liang 9 qian 9 fen $4 \mathrm{li}$

Caijie (Income statement)

Yongqing steamship

Yu 21,931 liang 8 qian 3 fen 7 li

Fuxing steamship

Yu 14,673 liang 6 qian 5 fen 7 li

Liyun steamship

Yu 35,063 liang 3 li 
Hezong steamship

Haijin steamship

Pingan steamship

Water transportation rice loss

$\mathrm{Su}$ Water transportation Miscellaneous

Zhe Water transportation Miscellaneous

Warehouse rents revenues

Carrying goods and barge forces

Terminal charges

Steamships self-insurances

Total $\mathrm{Yu}$

Yidun steamship loss

Shanghai and Tianjin warehouse expenses

Warehouse rents expenses

Donations for aids of natural disaster in the Jin District

Interests

Official debts interest

Gufen guanli dividends

Total Zhi

Net profits

Depreciation

Retained earnings
Yu 7,681 liang 6 qian 4 fen 9 li

Yu 6,125 liang 5 qian 3 fen 5 li

Yu 335 liang 7 fen 9 li

Yu 14,296 liang 8 qian 3 fen 9 li

Yu 2,518 liang 4 qian 8 fen 5 li

Yu 2,320 liang 2 qian 2 fen 5 li

Yu 709 liang 1 fen 4 li

Yu 6,031 liang 6 qian 4 fen Yu 680 liang

Yu 4,770 liang

Yu 117,136 liang 9 qian 6 fen 3 li

Zhi 16,426 liang 8 qian 1 fen 5 li

Zhi 14,460 liang 2 fen 3 li

Zhi 4,641 liang 8 qian 4 fen 5 li

Zhi 2,139 liang 4 qian 9 fen 3 li

Zhi 8,949 liang 6 qian

Zhi 8,733 liang 6 qian 2 fen

Zhi 47,600 liang

Zhi 102,951 liang 4 qian 6 li

14,185 liang 5 qian 5 fen 7 li

12,000 liang

2,185 liang 5 qian 5 fen 7 li

Figure 5. Early indications of Chinese companies' accountability

Source: Qián (1874, 3-4)

Notes:

1. Cun (to record liabilities and equity), Gai (to record assets and credits), $Y u$ (to record receipt of revenue), Zhi(to record payments of expenditure)

2. Silver weight sunit: 1 liang=10qian=100 fen $=1000 \mathrm{li}$

In the Qing dynasty, the unit of silver weights was used as the silver (money) unit.

Another accounts summary of CMSN is depicted in Figure 6 below.

\section{The $13^{\text {th }}$ Accounts Summary of CMSN \\ Zongjie (Balance sheet)}

Gai Capital

Gai Official debts

Gai Official continual debts

Gai Insurance capital

Gai Guichi capital

Gai dividends for Guichi capital
2,000,000 liang

832,274 liang 5 qian 1 fen 337,947 liang 1 qian 5 fen 9 li 600,000 liang 209,904 liang 6,696 liang 9 qian 
Gai Foreign debts

Gai Merchants debts

Gai Transactions deposits

Gai Interests preparation

Gai Dividends preparation

Gai Selling stocks

Gai Steamships self-insurance

Gai Retained earnings from the Caijie (income statement) Total Gai

Cun Guichi appropriation payable by Kaiping mine

Cun Money units current accounts

Cun Accounts receivable

Cun Transactions accounts receivable

Cun Tongwen bookstore southern warehouse mortgages

Cun Interests receivable

Cun Conscription advances

Cun Foreclosure goods remittance preparations

Cun Coal

Cun Investments Kaiping mine

Cun Loans to Korea

Cun accounts, stocks, buildings receivable

Cun Cash(silver)

Total Cun

Cun Yongqing steamship

Cun Fuyou steamship

Cun Rixin steamship

Cun Baoda steamship

Cun Fengshun steamship

Cun Jiangkuan steamship

Cun Jiangyong steamship

Cun Zhendong steamship

Cun Haiyan steamship

Cun Haichen steamship

Cun Haiding steamship

Cun Jiangtian steamship

Cun Jiangbiao steamship

Cun Jiangfu steamship

Cun Jiangtong steamship

Cun Yongning steamship

Cun Jiangping steamship

Cun Zhiyuan steamship

Cun Gongbei steamship

Cun Tunan steamship
578,101 liang 1 fen

82,641 liang 1 qian 9 fen 3 li 316,826 liang 7 qian 4 fen 6 li 20,268 liang 2 qian 6 fen 8 li 140,000 liang 2,629 liang 6 qian 2 fen 5 li 90,456 liang 2 qian 6 fen 131,960 liang 4 qian 1 fen 5 li 5,349,706 liang 8 fen 6 li

38,967 liang 4 qian 9 fen 4 li

96,995 liang 8 qian 2 fen 31,817 liang 4 qian 2 fen 8 li 93,572 liang 7 qian 3 li 70,000 liang

22,172 liang 7 qian 7 fen 8 li 24,796 liang 8 qian 4 fen 8 li

10,192 liang 7 qian 7 fen 36,557 liang 7 qian 6 fen 6 li 210,000 liang 210,000 liang

367,271 liang 2 qian 8 fen 5 li 68,361 liang 1 qian 9 fen 4 li 1,280,706 liang 8 fen 6 li 55,000 liang 90,000 liang 60,000 liang 76,000 liang 76,000 liang 114,000 liang 114,000 liang 75,000 liang 95,000 liang 90,000 liang 95,000 liang 110,000 liang 33,000 liang 114,000 liang 40,000 liang 12,000 liang 14,000 liang 120,000 liang 62,000 liang 130,000 liang 
Cun Puji steamship

Cun Jiangyu steamship

Cun Fushun steamship

Cun Guangli steamship

Cun Meifu steamship

Total Cun Steamships

Cun Ferry $6^{\text {th }}$

Cun Barges $11^{\text {th }}$

Cun Barges at each port

Total Cun Ferry and barges

Cun Shanghai eastern warehouses

Cun Shanghai northward warehouses

Cun Shanghai central warehouses

Cun Shanghai southward warehouses

Cun Shiliu commercial real estate

Cun Tianjin warehouses

Cun Tongzhou warehouses

Cun Yantai warehouses

Cun Yichang warehouses

Cun Hankou warehouses

Cun Jiujiang warehouses

Cun Wuhu warehouses

Cun Zhenjiang warehouses

Cun Ningbo warehouses

Cun Wenzhou warehouses

Cun Fuzhou warehouses

Cun Shantou warehouses

Cun Aomen warehouses

Cun Xianggang warehouses

Cun Timbers for coast defense houses

Cun Timbers for Shunan houses

Total Cun warehouses and timbers

Cun Cash for Investments of subsidiaries

Cun Rice and sack

Total Cun

Total above Cun

\section{Caijie (Income Statement)}

Jin Revenue of various steamships

Jin Revenue of Dagu barge

Jin Revenue of water transport bureaus

Jin Revenue of various steamships water transport labors

Jin Revenue of northward warehouse

Jin Revenue of warehouses rents of guests goods

Jin Revenue of rents of commercial estates

$$
\begin{aligned}
& \text { 75,000 liang } \\
& \text { 190,000liang } \\
& \text { 180,000 liang } \\
& \text { 180,000 liang } \\
& \text { 90,000 liang } \\
& \text { 2,300,000 liang } \\
& \text { 6,000 liang } \\
& \text { 115,000 liang } \\
& \text { 3,000 liang } \\
& \text { 134,000 liang } \\
& \text { 8,000 liang } \\
& \text { 260,000 liang } \\
& \text { 120,000 liang } \\
& \text { 600,000 liang } \\
& \text { 14,000 liang } \\
& \text { 170,000 liang } \\
& \text { 5,000 liang } \\
& \text { 2,000 liang } \\
& \text { 2,000 liang } \\
& \text { 186,000 liang } \\
& \text { 70,000 liang } \\
& \text { 20,000 liang } \\
& \text { 50,000 liang } \\
& \text { 10,000 liang } \\
& \text { 4,000 liang } \\
& \text { 28,000 liang } \\
& \text { 7,000 liang } \\
& \text { 5,000 liang } \\
& \text { 20,000 liang } \\
& \text { 22,000 liang } \\
& \text { 12,000 liang } \\
& \text { 1,615,000 liang } \\
& \text { 10,000 liang } \\
& \text { 20,000 liang } \\
& 30,000 \text { liang }
\end{aligned}
$$

5,349,706 liang 8 fen 6 li

498,554 liang 8 qian 2 fen 5 li

6,821 liang 1 qian 2 fen 5 li

13,014 liang 8 qian $6 \mathrm{li}$

16,675 liang 1 qian 1 fen

21,247 liang 2 qian 3 fen

52,356 liang 6 qian 7 fen 5 li

41,936 liang 5 qian 4 fen 9 li 
Jin Old materials

Total Jin

Zhi Rents paying to Shanghai lands

Zhi Various repair costs

Zhi Various fees paid

Zhi Various interests paid

Zhi Stocks guanli dividends

Total Zhi

Net income after the Jin less Zhi

Last Caijie retained earnings

Net income for depreciation and Yuli dividends

Depreciation for various steamships

Stocks Yuli dividends

Net income for remunerations

Remunerations for executive secretary and clerks

Caijie Retained earnings
1,566 liang 1 fen

652,172 liang 3 qian 3 fen

27,411 liang 5 qian 8 fen 6 li

74,689 liang 8 qian 4 fen 3 li

85,214 liang 4 qian 6 fen 6 li

143,709 liang 8 qian 8 fen 8 li

120,000liang

451,025 liang 7 qian 8 fen 3 li

201,146 liang 5 qian 4 fen 7 li

115,733 liang 1 qian 9 fen 2 li

316,879 liang 7 qian 3 fen 9 li

157,974 liang 3 fen 9 li

20,000 liang

138,905 liang 7 qian

6,945 liang 2 qian 8 fen 5 li

131,960 liang 4 qian 1 fen 5 li

Figure 6. A further example of an 'accounts summary'

Source: Qián (1887, appendix)

Note:

1. Cun (to record stocks of assets and credits)(stocks), Gai (to record claims on assets, including capitals and liabilities)(claims), Jin (to record receipts of revenues) (receipts), Zhi (to record payment of expenditure)(payments)

2. silver weights units: 1 liang $=10$ qian $=100 \mathrm{fen}=1000 \mathrm{li}$

In the Qing dynasty, the unit of silver weights was used as the silver (money) unit. 
A translation of Figure 7 outlines the import of CMSN's constitution.

\section{Part of CMSN's constitution regulations}

CMSN's various types of expenses should be limited. It was essential for every department to be frugal.5\% of revenues of steamships that transported food and people were to pay for meals and miscellaneous expenses of directors and senior managers (shangzong and dongshi ren).Rice expenses were the main expenses of directors and senior managers (shangzong and dongshi ren) if the rice was in the warehouses. If the rice was on the steamships, their monthly expenses should be limited and be settled at the end of year. All revenues of transport should be used to pay the guanli dividends of common stock capital at the rate of $10 \%$. The fixed yuli dividend rate was $80 \%$ of net income. $20 \%$ of net income was paid as remunerations for directors and senior manager (shangzong and dongshi ren). CMSN would discuss the specific payments of remuneration.

Figure 7. Part of CMSN's constitution regulations

Source: Jiāotōngbù Cáiwù Kuàijijú, Zhōngguó Jiāotōng Kuàijì Xuéhuì (1994) 
The translation of Figure 8 provides a glimpse of the clauses of the Gōngsī Lù.

\section{Part of Gōngsī Lù̀ (Gongsi lv, 1904 Company Law)}

Clause 107: Board of directors should annually supervise and lead general officers and general managers to prepare the annual reports after detailed settling the company's accounts.

Clause 108: After the auditors audit all accounts and sign without errors, directors could then settle the accounts.

Clause 109: Company's annual report should include: company's chu (payments) and ru (revenues) ledger; summary of company's current year business situation; company's current year profits or losses; interests and dividends determined by the board of directors and reserves (retained earnings); company's claims including common stock capital and accounts payable, assets and accounts receivable.

Clause 110: Annual reports prepared by the board of directors should be sent to the company headquarter and subsidiaries' offices before the $15^{\text {th }}$ of the month and for stockholders to review.

Clause 111: Company could no longer use common stock capital to pay dividends and pay dividends only when the company had profits.

Clause 112: $20 \%$ of net income also had to be reserved (retained earnings) until the retained earnings reached the value of one fourth of common stock.

Figure 8. Part of Gōngsī Lù̀ (Gongsi lv, 1904 Company law)

Source: Gōngsī Lù̀ (1904, 213-232) 
Appendix 2 - Glossary of terms used in the study

\begin{tabular}{|c|c|c|}
\hline Chinese Term & English Term & Definitions \\
\hline Qīng & Qing & Chinese dynasty overthrown by the revolution of 1911 \\
\hline guānlì & guanli & $\begin{array}{l}\text { a special form of Chinese dividend, fixed rate of } \\
\text { common stock }\end{array}$ \\
\hline Cíxī & Cixi & Empress Dowager \\
\hline Guăngdōng & Guangdong & a region of China \\
\hline sìzhùfă & sizhu fa & four-pillar balancing method \\
\hline sānjiăo zhàng & sanjiao zhang & three-leg bookkeeping method \\
\hline huòqīng bù & huoqing bu & cash sales and purchases journal \\
\hline yínqīng bù & yinqing bu & cash journal \\
\hline wănglái bù & wanglai bu & personal account and transfer journal \\
\hline lóngmén zhàng & longmen zhang & 'dragon-gate bookkeeping' method \\
\hline hé lóngmén & he longmen & matching process \\
\hline jìn & jin & revenue \\
\hline jiăo & jiao & expenditure \\
\hline cún & cun & assets \\
\hline gāi & gai & owners' equity and liabilities \\
\hline Jìn-Jiăo & Jin-Jiao & revenue-expenditure \\
\hline Cún-Gāi & Cun-Gai & asset-equity-liability \\
\hline sìjiăo zhàng & sijiao zhang & 'four-leg bookkeeping' method \\
\hline căixiàng report & caixiang report & profit-and-loss statement \\
\hline cúngāi report & cungai report & balance sheet \\
\hline căoliú & caoliu & memorandum \\
\hline căomă & caoma & commercial numerals \\
\hline xìliú & xiliu & journal \\
\hline hàntĩ & haiti & standard numerals \\
\hline zǒngqīng & zongqing & ledger \\
\hline kuàijì tĭ & kuaiji ti & accounting numerals \\
\hline Zōngjié & Zongiie & balance sheet \\
\hline Cǎijié & Caijie & income statement \\
\hline báihuà & baihua & vernacular \\
\hline guāndū shāngbàn & guandu shangban & officials supervised the operations of merchants \\
\hline gǔfèn zīběn & gufen ziben & common stock \\
\hline yúlì dividends & yuli dividends & flexible or fixed rate dividends \\
\hline $\begin{array}{l}\text { shāngzǒng and } \\
\text { dǒngshì rén }\end{array}$ & $\begin{array}{l}\text { shangzong and } \\
\text { dongshi ren }\end{array}$ & directors and senior managers \\
\hline Gōngsī lǜ & Gongsi lv & 1904 C ompany law \\
\hline $\begin{array}{l}\text { gōngkuăn cún } \\
\text { xiàng }\end{array}$ & $\begin{array}{l}\text { gongkuan cun } \\
\text { xiang }\end{array}$ & State debt \\
\hline $\begin{array}{l}\text { gōngkuăn } \quad x \overline{1} \\
\text { xiàng }\end{array}$ & gongkuan xi xiang & interest of the State debt \\
\hline zǒngbàn & zongban & government officers \\
\hline
\end{tabular}




\begin{tabular}{|l|l|l|}
\hline kuàibàn & kuaiban & government officers \\
\hline bāngbàn & bangban & government officers \\
\hline $\begin{array}{l}\text { shēnľ̌ng } \\
\text { shāngbàn }\end{array}$ & shenling shangban & firms led by gentlemen who left the government \\
\hline Shuōluè & Shuolue & narrative description of the firm's situation \\
\hline
\end{tabular}

